\title{
УUCTEUTBO3HABCTBO
}

УДК 792.03

DOI https://doi.org/10.24919/2308-4863/34-4-1

\author{
Наталія ОРЕШНІКОВА, \\ orcid.org/0000-0003-1955-6191 \\ заслужена артистка Украӥни, \\ викладачка кафедри мистецьких дисииплін \\ Ужггородського інституту культури і мистецтв \\ (Ужгород, Україна) orieshnikova6493-12@national-univesity.info
}

Ганна ЛИПЧЕЙ, orcid.org/0000-0001-8162-5261

студентка кафедри мистеиьких дисииплін Ужсгородського інституту культури і мистеитв (Ужгород, Украӥна) h.lypchei@unesp.co.uk

Діана ВИШНЕВА, orcid.org/0000-0002-7233-2691

студентка кафедри мистеиьких дисииплін Ужггородського інституту культури і мистеитв (Ужгород, Україна) vyshneva.d12@murdoch.in

\section{ФОРМУВАННЯ РЕЖИСЕРСЬКОЇ КУЛЬТУРИ ТА РОЗВИТОК МАЙСТЕРНОСТІ АКТОРІВ У СУЧАСНОМУ ОСВІТНЬОМУ ПРОЦЕСІ}

\begin{abstract}
У даному науковому дослідженні обговорюються питання історії театру, режисури та майстерності акторського виконання у структурі сучасного освітнього прочесу та виховання майбутнього актора. Різноманітні питання історії розвитку сучасного театру, а також пов'язані з ними питання акторської майстерності та виховання майбутніх акторів активно досліджуються протягом усієї історії розвитку театральної сцени та викликають широке розмаїття оиінок і стверджень. Важливість подібних питань зумовлюється великим значенням театральної культури в контексті формування загальносвітової культури загалом та значенням належного виховання майбутніх акторів із точки зору подальшого розвитку театральної сцени й формування в населення гідного, поважного ставлення до історії театру в контексті школи акторської майстерності та виховання якісних акторів. Актуальність зазначеної тематики дослідження зумовлюється необхідністю об'єктивного висвітлення питань історії театру та формування акторської майстерності з огляду на наявні театральні традииії і умови сьогодення. Методологія даного наукового дослідження має у своїй основі поєднання системного підходу щзодо визначення сутності головних питань, щчо винесено в його тематику, та глибокого аналізу різних аспектів, що мають значення в контексті розгляду історії сучасного театру та режисури й формування акторської майстерності на різних стадіях виховання майбутнього актора. Головними результатами, отриманими в ході даного наукового дослідження, можна вважати визначення головних чинників розвитку акторської майстерності в теперішній час та окреслення можливих перспектив розвитку сучасного театру $з$ огляду на ретроспективу формування режисерської та акторської майстерності в театрі минулому. Перспективи подальших наукових досліджень полягають у різноманітності освітлення кола питань, що стосуються театральної історії та традииій, а також створення належний умов щодо якісного виховання майбутніх акторів із точки зору сприйняття ними суті традицій театру та їх дотримання.
\end{abstract}

Ключові слова: театральна режисура, акторська майстерність, розвиток театру сучасності. 


\title{
Nataliia ORIESHNIKOVA, orcid.org/0000-0003-1955-6191 \\ Honored Artist of Ukraine, \\ Senior Lecturer at the Department of Artistic Disciplines \\ Uzhhorod Institute of Culture and Arts (Uzhhorod,Ukraine) orieshnikova6493-12@national-univesity.info
}

Hanna LYPCHEI, orcid.org/0000-0001-8162-5261 Student at the Department of Artistic Disciplines Uzhhorod Institute of Culture and Arts (Uzhhorod,Ukraine)h.lypchei@unesp.co.uk

Diana VYSHNEVA, orcid.org/0000-0002-7233-2691

Student at the Department of Artistic Disciplines Uzhhorod Institute of Culture and Arts (Uzhhorod,Ukraine) vyshneva.d12@murdoch.in

\section{DEVELOPMENT OF DIRECTING CULTURE AND ACTING SKILLS IN THE MODERN EDUCATIONAL PROCESS}

\begin{abstract}
This study discusses the history of theatre, directing and acting skills in the structure of the modern educational process and training of the future actor. Various issues of the history of modern theatre, as well as related issues of acting and education of future actors are actively explored throughout the history of the theatre scene, and cause a wide variety of opinions and statements. The importance of this subject is conditioned by the great importance of theatre culture in the context of global culture in general and the importance of proper education of future actors in terms of further development of the theatre scene and the development of a decent, respectful attitude towards theatre history in the context of acting and education of quality actors. The relevance of this study is conditioned by the need for objective coverage of the history of theatre and the development of acting skills considering the existing theatrical traditions and modern conditions. The methodology of this study is based on a combination of a systematic approach to determining the essence of the main issues raised in its subject, and in-depth analysis of various aspects relevant in the context of modern theatre history and directing and acting at different stages of actor's training. The main results obtained during this study can be considered to determine the main factors in the development of acting skills in the present and outline possible prospects for the development of modern theatre given the retrospective of the development of directing and acting skills in theatre in the past. Prospects for further study are to diversify the coverage of issues related to theatre history and traditions, as well as to create appropriate conditions for quality education of future actors in terms of their perception of the essence of theatre traditions and their observance.
\end{abstract}

Key words: theatrical directing, acting skills, development of modern theatre.

Постановка проблеми. Минуле XX століття визнане століттям розквіту режисерського театру. Починаючи 3 реформ Московського художнього театру та до кінця тисячоліття режисура вийшла на перше місце в театральному мистецтві. Розширилися функції режисера. Він стає адміністратором, а також тлумачем, інтерпретатором п'єси, «дзеркалом», що відображає індивідуальні якості актора, організатором всього творчого процесу підготовки вистави. Народження великих акторських особистостей пов'язано 3 тією чи іншою школою: системою Станіславського, Мейєрхольда, Вахтангова, Таїрова, Попова, Товстоногова та інших. Високий рівень професійної майстерності, основи якого були отримані під керівництвом майстрів у школах та студіях, дозволяли багатьом акторам легко адаптуватися в будь-якому режисерському малюнку (Сазонова, 2012: 160).
Сьогодні існує чимало шкіл, академій та інститутів, що випускають акторів для професійного театру. Накопичено величезний досвід формування особистості актора та виховання його професійних якостей. Традиції в мистецтві театру грають важливу роль, здійснюючи безперервну естетичну спадковість. Український театр протягом століть тримав свою самобутність, національний колорит, театральну школу освіти. Нічого не виникає на порожньому місці, але нічого не повторюється. Неодноразові традиції призводить до простого копіювання, епігонству. Діалектичне співвідношення між традицією та інновацією, старим та новим передбачає, принаймні, деякі важливі моменти, щоб мати на увазі, замислюватися про створення вистави та пам'ятати про необхідність розвитку мистецтва сучасного театру (Тополев, 2016: 176). 
У мистецтві театру нове народжується на межі різних художніх течій, що призводить до синтезу іноді суперечливих принципів. Конкретика співіснування художніх течій, доза взаємних «ін'єкцій» у кожному випадку - свої, їх власні, унікальні, $е$ предметом соціального аналізу громадських організацій мистецтвознавства. При цьому життєдіяльність нового, що було створене в результаті синтезу традиційних форм, завжди залежить від відповідності історичних умов та великих особистостей. Такими особливостями для українського театру є два напрямки. Перший спрямований на поліпшення, поглиблення психологічного аналізу в театрі, грунтується на традиціях Художнього театру, Малого театру періоду його розквіту, естетики, театральних поглядах класиків театрального мистецтва. Другий пов'язаний з українським романтизмом, акторським мистецтвом та розвитком майстерності акторів, створенням нових форм акторського виконання, активним розвитком образного, метафоричного, поетичного образу театральних вистав завдяки мистецтву режисури, творчості таких майстрів, як В. Лизогуб. В. Айзенштадт, О. Таїров (Тополев, 2016: 177).

Властиві для певних часів культурні течії накладали свій власний відбиток на процеси розвитку сучасного театру та виконавської майстерності акторів у контексті втілення на практиці режисерських задумів. На цьому тлі розвиток українського театру в минулому столітті та в перші два десятиріччя, що минули, століття теперішнього має свої характерні особливості, що позначаються на формуванні режисерської культури та розвитку майстерності акторів на теперішньому етапі сучасного освітнього процесу, з точки зору якісного виховання майбутніх українських акторів.

Аналіз досліджень. Дослідження питань формування виконавської майстерності майбутніх акторів, їхнього виховання в контексті визначення головних етапів розвитку сучасного театрального мистецтва та історії театру загалом знайшли своє якісне відображення в наукових дослідженнях В. Ю. Тополевського (2016), В. А. Сазонової (2012), А. В. Чепиноги (2016), С. Б. Войтківського (2014) та інших дослідників історії театру та традицій розвитку та формування акторської майстерності. Автори всебічно висвітлюють різні аспекти розвитку театральної сцени в контексті часів, що висвітлюються, та досліджують широке розмаїття питань виховання акторів та впливу винаходів театральної режисури на становлення акторської майстерності загалом та окремих виконавців зокрема. Крім того, в дослідженнях указаних та інших вчених йдеться про перспективи розвитку театральної сцени в контексті часу та 3 боку вивчення різних аспектів впливу режисури на якість театральної постановки та вміння акторів втілювати в реальність різноманітні режисерські ходи, як наслідок - належним чином поставлений процес виховання майбутніх акторів.

Мета статті полягає у визначенні головних чинників формування майстерності акторів у контексті розвитку театру, формуванні режисури театральної сцени стосовно різних часових етапів розвитку театру та якісному відображенні головних тенденцій розвитку театру з огляду на питання виховання акторів та створення акторської майстерності в сучасному освітньому процесі, що має місце під час подальшого розвитку театральної сцени в контексті часу, що минув, та майбутнього.

Виклад основного матеріалу. Теоретично стає зрозумілим, що манера акторської гри, професійні навички, система цінностей театрального мистецтва суттєво змінилися за останні півтора століття, з урахуванням тенденцій, що мали місце у процесі розвитку театрального мистецтва у вказаний період часу. Але відстежувати ці зміни протягом тривалого часу, занадто складно: нове i при цьому художньо переконливе сприймається як закономірне, логічне та природне явище, та й зміни у викладанні акторської майстерності не так очевидні, як, наприклад, зміни в манері акторського виконання. Відмінність між манерою акторського виконання явно проявляється, лише коли переглядаємо старі фільми (Генова, 2018: 153). Навіть гра колись видатних майстрів, що так зачаровувала глядачів до сліз, сьогодні сприймається як неправдива, надмірно награна, пристрасті - гіперболізованими, навіть гротесковими, а жести - умовними (Степанова, 2016: 170). Більш складним $є$ стан справ із розвитком художніх форм викладання, особливо технічних прийомів, які оновлюються й удосконалюються відповідно до вимог театрального мистецтва.

Можна стверджувати, що зміни та диверсифікації засобів вираження будь-якого мистецтва, зокрема акторського, пов'язані з удосконаленням громадського життя людей, інтенсивності їхньої духовної діяльності, впровадженням прийомів, методів художнього, уявного розуміння світу. Художньо-творча істина досягається не тільки єдиним певним засобом, а й безмежною безліччю форм, методів та прийомів. Цей естетичний закон сприяє синтезу різних творчих систем, які у своєму чистому вигляді існують в історично обмеженому часу, активно взаємодіючи із, здавалося б, протилежними художніми системами. Корот- 
кий історичний пошук викладання майстерності актора, домінуючою складовою частиною якого був досвід педагогів, прихильників класичної освіти, у якого був створений особливий стиль психолого-педагогічний підхід до студентів, із його соціальним аналізом та глибокою увагою до статусу та душі майбутнього актора. Гуманістичний пафос захисту студентів, класовий аналізу історії, творчий підхід до виховання, із прийняттям до уваги всього комплексу ідей педагога-майстра - головні компоненти колективної роботи українських педагогів (Тополевский, 2016: 178).

Останнім часом дуже показовим фактом $є$ вельми напружені та активні дослідження у сфері педагогіки творчої діяльності, а також створення творчих лабораторій в умовах діяльності вищих навчальних закладів. Цьому сприяють активні пошуки майстрів педагогічної діяльності нових шляхів удосконалення зв'язків між класикою та сучасністю у викладанні акторської майстерності, що має сприяти вихованню майбутнього актора в руслі вірності традиціям класичного театрального мистецтва 3 огляду на реалії сьогодення. Водночас має місце посилення інтересу до сучасної педагогіки та виховання акторської майстерності. До цього процесу долучаються молоді талановиті фахівці-педагоги, нові трактування форм та методів підтримує керівництво вузу. В останні роки інтенсивно збагачується матеріально-технічна база навчання акторської та режисерської майстерності (Войтковский, 2014: 33).

Протягом усієї історії розвитку театру, багатьох видатних діячів культури та мистецтв, а також провідних педагогів турбує питання низького професійного рівня підготовки акторських кадрів, відповідності акторського мистецтва вимогам сучасності. Сучасний театр є багатоманітним та відрізняється різноманітністю жанрів та театральних напрямків. За останній час спостерігається тенденція в деяких театрах залучати глядача тільки видовищністю, наближеністю та жанру шоу. У цьому ж театрі, розважаючись, вчаться жити, й відпочиваючи, збагачують себе (Сазонова, 2012: 160).

Якими би не були темпи теперішнього науково-технічного прогресу та рівень інновацій у сучасному суспільстві, у світі завжди існували тенденція неспинної боротьби за людську душу, на передньому краї якої завжди знаходилися представники театральної сцени та різноманітних творчих напрямків театрального мистецтва. Не втратили сучасності думки В. I. НемировичаДанченка, великого режисера та театрального педагога, про те, що головним завданням педа- гога $є$ : «Вловити індивідуальність, викликати до життя «іскорку», допомагати іiі подальшому розвитку; розчищати засміченість, облагороджувати смак, боротися 3 поганими звичками, із дрібним самолюбством: просити, наполягати, вимагати; пестити й карати; безперервно мати справу з людським матеріалом, насичувати його твоїми ідеями; 3 радістю і турботою стежити за найменшим його паростком ... Тут саме зерно театру, найглибша i захоплююча сутність його» (Сазонова, 2012: 161).

Сьогодні, на початку нового тисячоліття, все частіше виникає думка про головної ролі актора на сцені, питання його самоздійснення, самореалізації, постає питання про акторський театр. Здається, назріло підгрунтя протесту проти авторської, авторитарної режисури, перенасиченої постановочними прийомами, де акторові не відводиться головне місце, режисури, що експлуатує акторську творчість. У сьогоднішніх режисерських експериментах, антрепризах, незважаючи на зайнятість провідних акторів, мало відкриттів, лідерів. Найчастіше можна побачити грубість, відверту халтуру, спрощення, відмову від психологічного театру, погляд на театр тільки як на видовищне мистецтво, що не виховує, а розважає глядача. Тому помітна активізація тих акторів, яких турбують зниження загального професійного рівня, виникає потреба та бажання працювати 3 майстрами, такими, як П. Фоменко, Л. Додін, або прагнення самими ставити спектаклі. Заняття режисурою таких чудових акторів, як М. Казаков, С. Юрський, О. Янковський, О. Меньшиков говорятьпропрагненнявисунутинапершемісцеактора, а не постановочні прийоми (Плотникова, 2017: 27).

Акторське мистецтво - це безперервна робота душі та розуму (Тумашов, 2018: 243). Сьогодні визначальним у формуванні особистості актора $\epsilon$ діалектична єдність двох начал: збереження кращих традицій, фундаменту школи і безперервного експериментаторства, відкритості світу, часу. «Творчі зіткнення юності та зрілості, відваги і розумного консерватизму - основа будь-якої школи» (Лапина, 2000: 15).

Дуже цікавим у контексті даного наукового дослідження виступає точка зору представників колективу педагогів Санкт-Петербурзького Університету культури та мистецтв на проблеми акторського виховання та театральної освіти в реаліях сучасності. На думку пітерських педагогів, «дуже важливими проблемами театральної освіти на теперішній час $є$ фінансова та економічна - забезпечення навчального процесу сучасною технологією: комп'ютерами, відеомагнітофонами й необхідною навчальною літературою. 
Кафедра сценічних мистецтв ТГУ імені Г. Р. Державіна, видаючи методичні посібники, програми по курсам, монографії, якимось чином вирішує ці проблеми, але держава, університет мало допомагає. Оформлення аудиторій, приготувань ширм, кубів здійснюється на курсах, за рахунок зароблених від вистав грошей, але не вирішує проблеми випуску та підготовки професійного навчального спектаклю. Більшість вистав оформляється з підсобного матеріалу умовно. На кожному курсі доводиться проявляти чудеса винахідливості, щоб створити зоровий образ вистави. Правда, за останній час ситуація змінилася, та університет виділяє гроші на оформлення навчальних вистав» (Плотникова, 2017: 28-29).

Таким чином, отримання театральної освіти на теперішній час $\epsilon$ вельми непростою справою, та пов'язано це з багатьма проблемами сучасного суспільства, що торкаються не лише театру а й інших сфер культурного життя. Але завдяки наполегливій праці педагогічних колективів сучасних вузів вдається створити належні умови щодо підтримання на належному рівня якості викладання акторської майстерності та інших складових частин театрального мистецтва, що $є$ надзвичайно важливим із точки зору зберігання театральний традицій та формування надійної основи розвитку сучасного театру у майбутньому (Чепинога, 2016: 77-78).

Спираючись на думку багатьох дослідників історії театральної сцени та педагогічного досвіду діячів культури та мистецтв, можна стверджувати, що використання традиційних прийомів театральної педагогіки допомагає природному творчому та освітньому процесу. Саме традиційні прийоми театральної педагогіки здійснюють позитивний емоційний вплив на процес формування майстерності режисерів та акторів, підвищують результативність навчання й роблять його більш плідним, збільшують інтерес до майбутньої професії та підсилюють мотивацію. Це є дуже суттєвим із точки зору погляду на історичний контекст розвитку режисерської та акторської майстерності та має значення в теперішніх реаліях театрального мистецтва.

Навчити мистецтву режисера (актора) не можна, режисером (актором) слід бути «від бога», але створити сприятливі умови для вільного розвитку таланту й можна, й потрібно (Флоря, Лосаберидзе, 2017: 118). У цьому полягає завдання театральної педагогіки: створити умови та правила, щоб актор та режисер не навчалися, а вчилися самі. Виховання режисера та актора відбувається не тільки у класі, але й за його межами. Виховує місто, виставки та подорожі, легенди та пам'ятники, значущість та художність того серед- овища, що його оточує і $є$ справжнім вихователем актора, режисера. Найідеальнішою школою режисера $\epsilon$ сам театр. Сучасність театру, його повітря, атмосфера, причетність із ним та через нього 3 «мистецтвом», «культурою», «великий реальної дійсністю людства», можливість безпосередньої участі в ньому створюють сприятливі умови та стимулюють зростання таланту.

Висновки. Професійна освіта майбутніх акторів і режисерів - унікальний навчально-виховний процес, спрямований на розвиток випускників як унікальних творчих особистостей. Зміст такої освіти має грунтуватися на класичній театральній культурі, свободі творчості, духовності та моральності. Як показує проведений теоретичний аналіз науково-методичної педагогічної літератури, сьогодні у професійній підготовці студентів театральних спеціальностей застосовується система традиційних та інноваційних методів та засобів навчання. Вони відображають специфічні особливості профільного навчання й подальшої творчої роботи майбутніх акторів та режисерів.

Кращі традиції вітчизняної театральної школи відображають процес професійної підготовки майбутніх акторів і режисерів як єдиний цілісний процес навчання та виховання у вищих навчальних закладах. Єдність виховання й навчання майбутніх акторів та режисерів актуалізує значимість когнітивного, мотиваційного, ціннісно-смислового, емотивного та художнього компонентів формування майбутніх фахівців як яскравих творчих особистостей. У цьому процесі цілісність виражається в сукупності придбаних художньо-ціннісних знань про театр, драматургію, про музику, природу творчості та про багато іншого. У цілісному підході великого значення набуває виховний аспект професійної підготовки, що відображає гостру необхідність духовно-морального, естетичного, світоглядного розвитку, формування художніх професійних ідеалів майбутніх фахівців. Усі ці якості випускників театральних спеціальностей формуються в процесі виховання та навчання у вузі та в процесі самостійної роботи над собою.

Одним з імперативів ефективної професійної підготовки фахівців у галузі театрального мистецтва $€$ їх формування як творчих особистостей із високим рівнем розвитку цивільних, особистісних та професійно важливих якостей. У цьому процесі особливе місце займає проблема активізації та розвитку фантазії, творчої уяви, перш за все - художньо-образного мислення, так необхідного акторові та режисерові для створення цілісного сценічного образу вистави, передачі образу, народженого у свідомості драматурга. Художньо- 
образне мислення в театральному мистецтві корінне питання в пізнанні глибинних процесів театральної творчості.

Таким чином, необхідна динамічна організація професійної підготовки студентів у навчальнотворчому процесі вузу, за якої цілеспрямовано будуть поєднуватися елементи навчання, вихо- вання, формування професійно важливих якостей, самостійності та активності студентів. Головне - як можна уважніше та повніше розкрити індивідуальність студента-театрала, розвивати в кожному майбутньому акторі або режисері саме йому властиві творчі здібності та оригінальний творчий почерк.

\section{СПИСОК ВИКОРИСТАНИХ ДЖЕРЕЛ}

1. Войтковский С. Б. История русского театра - история частной инициативы. Театр. Живопись. Кино. Музыка. 2014. № 6. С. 33-44.

2. Генова Н. М. Условия активизации лидерского потенциала будущих актеров в процессе обучения. Вестник Московского государственного университета культуры и искусств. 2018. № 6(86). С. 151-156.

3. Лапина Г. П. Образование и искусство. Театральная жизнь. 2000. № 8. С. 15-17.

4. Плотникова К. П. Современные проблемы театрального образования. Санкт-Петербургский образовательный вестник. 2017. № 8. С. 27-29.

5. Сазонова В. А. Традиции и новаторство в преподавании современного актерского искусства. Социальноэкономические явления и прочессы. 2012. № 4. С. 160-165.

6. Степанова И. В. Традиционные приемы театральной педагогики в процессе обучения будущих актеров и режиссеров. Мир науки, культуры, образования. 2016. № 1(56). С. 169-171.

7. Тополевский В. Ю. Потенциал педагогической деятельности в театральной школе. Наука. Искусство. Кульmyра. 2016. № 1(9). С. 175-182.

8. Тумашов М. А. Проблемы художественно-нравственного воспитания актера и режиссера в процессе профессионального обучения в театральной школе. Ученые записки. 2018. № 3(17). С. 241-247.

9. Флоря В. И., Лосаберидзе К. Р. К проблеме формирования профессионально важных качеств студентов театральных специальностей как творческих личностей. Культура и образование: Научно-информационный журнал вузов культуры и искусств. 2017. № 5. С. 116-124.

10. Чепинога А. В. Проблемы воспитания современного режиссера оперного театра. Южно-Российский музыкальный альманах. 2016. № 4. С. 75-81.

\section{REFERENCES}

1. Chepinoga A. V. Problemyi vospitaniya sovremennogo rezhissera opernogo teatra [Problems of education of the modern director of the opera theater]. Yuzhno-Rossiyskiy muzyikalnyiy almanah, 2016, Nr 4, pp. $75-81$ [in Russian].

2. Florya V. I., Losaberidze K. R. K probleme formirovaniya professionalno vazhnyih kachestv studentov teatralnyih spetsialnostey kak tvorcheskih lichnostey [On the problem of the formation of professionally important qualities of students of theatrical specialties as creative personalities]. Kultura i obrazovanie: Nauchno-informatsionnyiy zhurnal vuzov kulturyi $i$ iskusstv, 2017, Nr 5, pp. 116-124 [in Russian].

3. Genova N. M. Usloviya aktivizatsii liderskogo potentsiala buduschih akterov v protsesse obucheniya [Conditions for activating the leadership potential of future actors in the learning process]. Vestnik Moskovskogo gosudarstvennogo universiteta kulturyi i iskusstv, 2018, Nr 6 (86), pp. 151-156 [in Russian].

4. Lapina G. P. Obrazovanie i iskusstvo [Education and art]. Teatralnaya zhizn, 2000, Nr 8, pp. 15-17 [in Russian].

5. Plotnikova K. P. Sovremennyie problemyi teatralnogo obrazovaniya [Modern problems of theater education]. Sankt-Peterburgskiy obrazovatelnyiy vestnik, 2017, Nr 8, pp. $27-29$ [in Russian].

6. Sazonova V. A. Traditsii i novatorstvo v prepodavanii sovremennogo akterskogo iskusstva [Traditions and innovation in teaching contemporary acting]. Sotsialno-ekonomicheskie yavleniya i protsessyi, 2012, $\mathrm{Nr} 4$, pp. 160-165 [in Russian].

7. Stepanova I. V. Traditsionnyie priemyi teatralnoy pedagogiki v protsesse obucheniya buduschih akterov i rezhisserov [Traditional methods of theatrical pedagogy in the process of teaching future actors and directors]. Mir nauki, kulturyi, obrazovaniya, 2016, $\operatorname{Nr} 1$ (56), pp. 169-171 [in Russian].

8. Topolevskaya V. Yu. Potentsial pedagogicheskoy deyatelnosti $\mathrm{v}$ teatralnoy shkole [The potential of teaching activities in the theater school]. Nauka. Iskusstvo. Kultura, 2016, Nr 1 (9), pp. 175-182 [in Russian].

9. Tumashov M. A. Problemyi hudozhestvenno-nravstvennogo vospitaniya aktera i rezhissera v protsesse professionalnogo obucheniya $\mathrm{v}$ teatralnoy shkole [Problems of artistic and moral education of an actor and director in the process of vocational training in a theater school]. Uchenyie zapiski, 2018, Nr 3 (17), pp. 241-247 [in Russian].

10. Voytkovskiy S B. Istoriya russkogo teatra - istoriya chastnoy initsiativyi [History of Russian theater - history of private initiative]. Teatr. Zhivopis. Kino. Muzyika, 2014, Nr 6, pp. 33-44 [in Russian]. 